rational series of reflexions corresponding to $d(001)$ of $9.4 \mathrm{kX}$

Lithium montmorillonite dried at $200^{\circ} \mathrm{C}$. shows a decreased exchange capacity to ammonium ions at $p \mathrm{H} 7$, when compared with samples dried at $70^{\circ} \mathrm{C}$. Wyoming bentonite showed a change from 90 m.equiv./100 gm. to 3 m.equiv./100 gm. Differential thermal analysis on lithium montmorillonite dried at $200^{\circ} \mathrm{C}$. and rehydrated at 50 per cent relative humidity showed that the endothermic peak between $100^{\circ}$ and $200^{\circ} \mathrm{C}$., due to sorbed water, was greatly decreased when compared with samples dried ${ }^{3}$ at $70^{\circ} \mathrm{C}$.

These changes of internal surface on drying at $200^{\circ} \mathrm{C}$. were not observed with authentic samples of beidellite (Black Jack Mine) ${ }^{6}$, saponite (Cathkin $\mathrm{Hill}^{2}$, hectorite (California) ${ }^{8}$ and two nontronites when saturated with lithium. It appears, therefore, that this decrease in internal surface takes place only when the mineral is dioctahedral and the charge in the silicate sheets is due predominantly to substitution in the octahedral layers. The test thus provides a useful method of distinguishing between the end members of the montmorillonite- beidellite series, which is a difficult procedure in the case of impure samples.

Grateful acknowledgment is made to the British Museum (Natural History), Geological Survey, and the Fullers Earth Union, Ltd., for gifts of minerals.

Pedology Department,

Rothamsted Experimental Station,

Harpenden, Herts. June 11.

${ }^{1}$ Garcia, F. Gonzalez, Anales de Edafologia y Fisiologia Vegetal, 9, $149(1950)$

Hofmann, U., and Klemen, R., Z, anorg. Chem., 262, 95 (1950).

${ }^{3}$ Greene-Kelly, R., Clay Minerals Bull., 1, 221 (1952).

- Brindley, G. W.; "X-Ray Identiflcation and Crystal Structure of Clay Minerals", 86 (London: Min. Soc., 1951)

- Brown, G., and Greene-Kelly, R. (to be published)

- Nagelschmidt, G., Min. Mag., 25, 140 (1938).

- Caillere, S., and Henin, S., Clay Minerals Bull., 1, 138 (1951).

'Ross, C. S., and Hendricks, S. B., "Minerals of the Montmorillonite Group", U.S. Geol. Surv. Prof. Paper No. 205-B (1945)

\section{Minimum Phosphate and Magnesium Requirements of Nitrifying Bacteria}

THE nutrient requirements of the autotrophic nitrifying bacteria are simple, but among the elements which seem to be essential for them are phosphorus and magnesium. Bömeke ${ }^{1}$ reported that Nitrobacter would not grow in media from which either phosphate or magnesium was omitted; and Nitrosomonas would not grow in medium with magnesium omitted. Wimmer ${ }^{2}$ found that phosphate was necessary for the growth of both organisms, but the minimum requirement was only $0.02 \mathrm{mgm}$. phosphorus per litre for both Nitrobacter and Nitrosomonas.

To find the minimum requirements of nitrifiers for these two elements, pure cultures were grown in 5 -ml. liquid medjum in test-tubes covered with aluminium caps. The control medium contained $M / 1,000$ phosphate and $M / 1,000$ magnesium sulphate. A series of transfers was made on media from which either the phosphate or the magnesium was omitted. The bacteria used were: a strain of Nitrosomonas europaea from Denmark ${ }^{3}$ and a strain of Nitrobacter winogradskii from Ampthill, Beds'. A drop from a Pasteur pipette was used as the inoculum, so that the dilution at each transfer was about a hundred times.

Phosphate. The Nitrosomonas survived no less than eleven successive transfers on to medium with phos- phate omitted; but no special steps were taken to purify the medium from every trace of phosphate, so a very small amount (too small to give the usual drop reaction for phosphate) may have been present. In any event, the amount carried over in the inoculum was very small ; after three transfers, only a fraction of a microgram would be carried over. Nitrobacter ceased to oxidize nitrite in the second transfer, but the bacteria survived, as transfers back on the control medium were normal. On the second transfer, the theoretical amount of phosphorus carried over in the inoculum would correspond to about $0.003 \mathrm{mgm}$. per litre.

Magnesium. Both species continued to oxidize ammonia or nitrite up to the fourth successive transfer on to medium with magnesium omitted. By this transfer, the theoretical amount of magnesium carried over in the inoculum would be about $0.0002 \mathrm{mgm}$. per litre. Both species survived, as transfers back to control medium grew.

Rothamsted Experimental Station,

JaNe MEIKLEJOHN

Harpenden, Herts. June 5.

2 Bömeke, H., Arch. Mikrobiol., 14, 63 (1949).

2 wimmer, G., Z. Hyg., 48, 135 (1904).

${ }^{3}$ Jensen, H. I., Nature, 185, 974 (1950).

‘ Melklejohn, J., J. Gen. Microbiol. (in the press).

\section{Sir Jack Drummond, F.R.S.}

THE news of the tragic death of Sir Jack Drummond came as a severe shock to his many friends in America. Only after the initial paralysing numbness associated with the sporadic news flashes of his murder had worn off could the enormity of this crime be appreciated. Although the loss to the scientific world has been great, a deep feeling of the personal loss of a friend has been experienced by many of us in Canada. Over the yoars Jack Drummond has made numerous Canadians his associates. His interest and hospitality was extended to many junior men of science, and all of us will remember the impact of his personality as he blended the science of nutrition and the art of entertainment into a formula as palatable as his Englishman's food. Perhaps no one has done so much to help so many Canadian medical research students attain a balanced perspective of scientific life in England. To many of us the pleasure of informal evenings, and the charm of Drummond as a host, will remain as our most vivid memory of a man who was truly more than a great man of science.

Department of Nutrition, H. D. Branion

Ontario Agricultural College, Guelph.

Department of Biochemistry,

GORdon BUTLER

University of Toronto, Toronto.

Department of Paediatrics,

Hospital for Sick Children,

Toronto.

L. Chute

Department of Paediatrics,

University of British Columbia, Vancouver.

Department of Medical Research, R. L. NoBLE

University of Western Ontario, London. 